\title{
Analisis Deformasi Praseismik Stasiun GPS Akibat Gempa di Segmen Mentawai Februari 2008
}

\author{
Dwi Pujiastuti', Deasy Arisa ${ }^{2}$, Regina Mai Anggriani Br. Sitanggang ${ }^{1}$, \\ Annisa Zahratul Hilma \\ ${ }^{1}$ Jurusan Fisika, Universitas Andalas, Padang, Indonesia \\ ${ }^{2}$ Pusat Penelitian Geoteknologi LIPI
}

\section{Info Artikel}

\section{Histori Artikel:}

Diterima: 7 November, 2019

Direvisi: 27 November, 2019

Diterbitkan: 1 Maret, 2020

\section{Kata kunci:}

deformasi

GAMIT/GLOBK

GPS

praseismik

SuGAR

\begin{abstract}
ABSTRAK
Telah dilakukan penelitian untuk melihat bentuk deformasi yang terjadi pada tahap praseismik gempa di Segmen Mentawai akibat gempa Februari 2008. Data GPS diolah menggunakan software GAMIT/GLOBK untuk mendapatkan koordinat estimasi beserta besar vektor pergeseran dari 7 stasiun GPS SuGAR di sekitar episenter gempa pada Day of Year (DoY) 01 sampai DoY 054 yang terjadi sebelum gempa Februari 2008. Hasil penelitian deformasi praseismik dari gempa Mentawai 2008 memperlihatkan tidak adanya anomali deformasi berupa akselerasi deformasi di 7 stasiun yang diamati. Nilai koordinat harian dari setiap stasiun hanya berubah dalam fraksi millimeter. Arah deformasi pada tahap praseismik sesuai dengan arah laju penunjaman Lempeng IndiaAustralia terhadap Eurasia yaitu North - East dengan besar deformasi stasiun BSAT (Bulasat) 5,9 mm, PRKB (Parak Batu) 4,2 mm, SLBU (Silabu) 103,46 mm, SMGY (Saumangayang) 35,16 mm, KTET (Katiet) 96,9 mm, PPNJ (Pulau Siburu) 0,77 mm, dan MKMK (Muko muko) 3,6 mm. Terjadi pemusatan energi pada daerah Pulau Sipora dan Pulau Pagai Utara yang ditandai dengan besarnya deformasi stasiun KTET, SLBU, dan SMGY dibandingkan stasiun BSAT, PRKB, PPNJ, dan MKMK pada tahap praseismik. Hal ini dibuktikan dengan posisi episenter Gempa Mentawai 2008 yang berada di daerah ini.
\end{abstract}

The form of deformation that during the pre-seismic phase of the earthquake in February 2008 in the Mentawai Segment has been investigated using SuGar GPS data. GPS data were processed using GAMIT / GLOBK software to obtain the coordinates along with the displacement vector magnitude of seven SuGAR GPS stations around the earthquake epicenter on Day of Year (DoY) 01 to DoY 054 that occurred before the February 2008 earthquake. No deformation anomalies in the form of accelerated deformation at seven stations. The daily coordinate of each station only changes in millimeter fraction The direction of deformation in the pre-seismic stage is following the rate of inclination of the Indian-Australian Plate to Eurasia, namely North East with a BSAT (Bulasat) station having deformation value of $5.9 \mathrm{~mm}, P R K B$ (Parak Batu) $4.2 \mathrm{~mm}$, SLBU (Silabu) $103.46 \mathrm{~mm}$, SMGY (Saumangayang) $35.16 \mathrm{~mm}$, KTET (Katiet) $96.9 \mathrm{~mm}$, PPNJ (Siburu Island) $0.77 \mathrm{~mm}$, and MKMK (Muko muko) $3.6 \mathrm{~mm}$. The energy concentrated in the areas of Sipora Island and North Pagai Island, which is indicated a more significant deformation magnitude the KTET, SLBU and SMGY stations BSAT, PRKB, $P P N J$, and MKMK stations during the pre-seismic stage. It is consistent with the epicenter position of the Mentawai Earthquake 2008, which is located in this area. 


\section{PENDAHULUAN}

Zona subduksi di Pulau Sumatera merupakan daerah pertemuan lempeng tektonik aktif yang sering melepaskan energi gempa bumi. Segmen Mentawai merupakan zona subduksi lempeng tektonik yang terletak di Kepulauan Mentawai. Kepulauan ini terletak di bagian barat Sumatera. Pada tanggal 24 dan 25 Februari 2008 terjadi gempa bumi berturut-turut dengan kekuatan $6.6 \mathrm{M}_{\mathrm{w}}, 7,2 \mathrm{M}_{\mathrm{w}}, 6.6 \mathrm{M}_{\mathrm{w}}$ dan 6,7 $\mathrm{M}_{\mathrm{w}}$. Total energi yang dilepaskan sepanjang Segmen Mentawai sampai tahun 2007 menurut penelitian Bock dkk. (2003) baru sekitar sepertiga energi yang terlepas dari total energi yang sudah terkumpul sejak gempa bumi tahun 1797 dan 1833. Oleh karena itu, gempa bumi tektonik dapat terus terulang di Segmen Mentawai. Perulangan gempa bumi tektonik ini disebut siklus gempa (Sarsito dkk., 2005; Ardiansyah, 2014; Efendi dkk., 2018).

Gempa bumi akan menyebabkan kerak bumi di sekitarnya terdeformasi, baik dalam arah vertikal maupun horizontal. Salah satu upaya yang dapat dilakukan dalam rangka pemantauan potensi dan mitigasi bencana alam gempa bumi yaitu melalui penelitian serta analisis mekanisme siklus dan tahapan gempa bumi.. Dalam suatu siklus terjadinya gempa bumi, proses deformasi dapat dibagi ke dalam beberapa tahapan, yaitu: interseismik, praseismik, koseismik, dan pascaseismik, (Natawidjaja dkk. 2007; Mori 2004; Sieh, dkk. 2000). Melalui pemantauan Global Positioning System (GPS) kontinu dapat diketahui pergerakan deformasi yang terjadi akibat gempa bumi. Beberapa penelitian telah dilakukan berkaitan dengan deformasi akibat gempa bumi di Segmen Mentawai. Sajagat dkk. (2016) mengukur deformasi di wilayah Mentawai akibat proses interseismic dari gempa Mentawai 2007. Penelitian deformasi fase pascaseismik pada Gempa Mentawai 25 Februari 2008 telah dilakukan oleh Muafiry dkk. (2014) guna menganalisis vektor pergeseran stasiun GPS Sumatran GPS Array (SuGAr) pada Gempa Mentawai 25 Februari 2008. Dari penelitian ini diketahui arah pergeseran stasiun SLBU, BSAT, PRKB yang terletak pada pulau Pagai Selatan pada fase postseismik adalah south-west, sedangkan stasiun PPNJ pada fase pascaeismik adalah south-east. Arah pergerakan stasiun yang berada pada Pulau Pagai Selatan ke arah south-west ini berbanding lurus dengan vektor pergeseran stasiun GPS pascaseismik Gempa Mentawai 2007 yang arah vektornya south-west. Hal ini disebabkan Gempa Mentawai 2008 merupakan rentetan aftershock dari Gempa Mentawai 2007 yang mengakibatkan destruktif di Sumatera (Yusfania, 2014).

Analisis deformasi pada tahapan gempa bumi merupakan suatu upaya dalam rangka pemantauan potensi dan mitigasi bencana, yaitu dengan memahami karakteristik siklus kegempaan dari suatu segmen. Pemantauan karakteristik deformasi pada tahap praseismik sangat diperlukan untuk melihat pola deformasi yang terjadi di suatu wilayah sebelum terjadinya gempa. Dalam penelitian ini digunakan data SuGAR sebelum gempabumi Mentawai Februari 2008 untuk melihat karakteristik deformasi yang terjadi di beberapa stasiun yang terpasang di sekitar episenter gempa

\section{METODE}

\subsection{Data}

Data yang digunakan pada penelitian ini adalah data hasil pengamatan GPS stasiun Sumatran GPS Data Array (SuGAR) terhadap gempa yang terjadi di Segmen Mentawai Februari 2008. Data stasiun SuGAr yang digunakan, yaitu: PPNJ, SMGY, PRKB, KTET, BSAT, SLBU, dan MKMK (Gambar 1). Day of Year (DoY) yang digunakan untuk pengamatan fase preseimik gempa adalah DoY 001-054. Persebaran stasiun SuGAR dan 4 episenter gempa yang digunakan dapat dilihat pada Gambar 1. Deformasi yang terjadi merupakan akumulasi dari 4 gempa bumi dengan skala $6.6 \mathrm{M}_{\mathrm{w}}, 7,2$ Mw, 6.6 Mw dan 6,7 Mwyang terjadi pada tanggal 24 dan 25 Februari 2008. Berdasarkan Gambar 1, kepulauan mentawai terdiri dari tiga pulau utama yaitu Siberut, Sipora, dan Pagai. Zona subduksi segmen mentawai terletak di sebelah timurlaut dari ketiga pulau tersebut. 


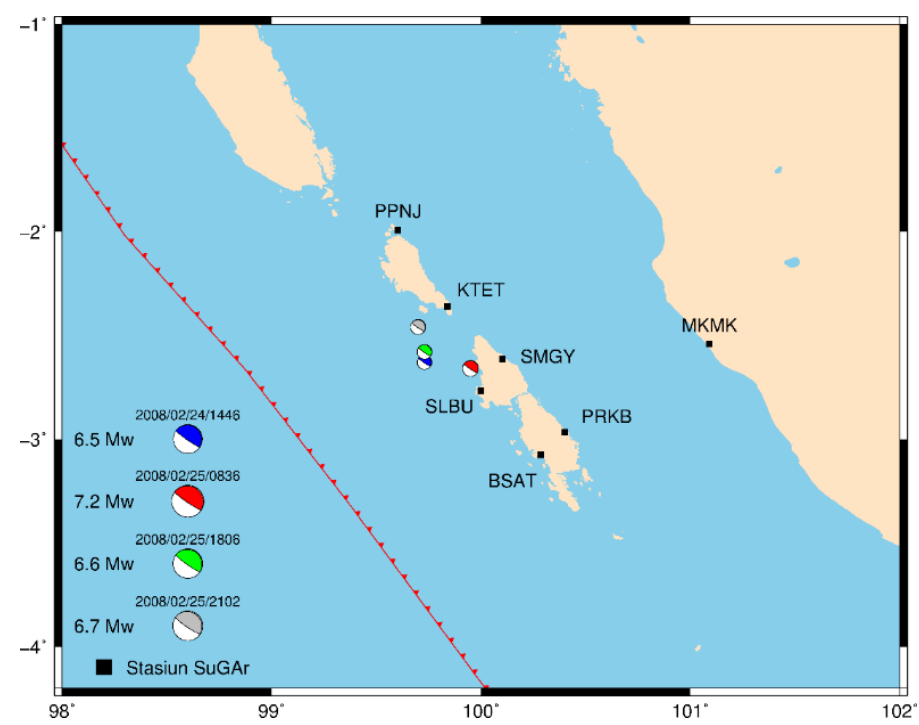

Gambar 1. Persebaran stasiun SuGAr dan episenter Gempa Mentawai 2008

\subsection{Pengolahan Data}

\subsubsection{Pengolahan Data Dengan GAMIT}

GAMIT adalah perangkat untuk analisis GPS yang komprehensif yang dikembangkan di Massachusetts Intitute of Technology (MIT), Harvard - Smithsonian Centre for Astrophysics (CFA) dan Scripps Institution of Oceanography (SIO) (Herring dkk. 2008). Perangkat lunak ini digunakan untuk mengestimasi tiga dimensi posisi relatif stasiun di bumi dan orbit satelit. Perangkat lunak ini dirancang untuk berjalan di bawah sistem operasi linux. Fungsi GAMIT yaitu, mempersiapkan data untuk diproses, menghasilkan orbit referensi untuk satelit, menghitung pengamatan residual dan turunan parsial dari model geometris, mendeteksi outliers atau jeda dalam data, dan melakukan analisis penyelesaian kuadran terkecil. Hasil dari GAMIT adalah solusi parameter estimasi dan covariances yang dapat diolah di GLOBK untuk memperkirakan posisi stasiun, kecepatan, parameter orbital, dan rotasi bumi (Aji, 2016).

\subsubsection{Pengolahan Data Dengan GLOBK}

GLOBK (Global Kalman filter VLBI and GPS analysis program) adalah perangkat lunak pemfilter data dengan metode Kalman filter, yang bertujuan untuk menggabungkan solusi dari pengolahan data primer dari geodesi satelit atau pengukuran terestris.. Hasil yang didapatkan dari pengolahan GLOBK adalah data posisi dari setiap stasiun SuGAr dan grafik time series yang menunjukkan pergerakan stasiun SuGAr. Selanjutnya akan diamati pergerakan posisi setiap stasiun GPS pada sumbu east $(E)$, north $(N)$, sehingga nantinya dapat diketahui besar pergeseran titik GPS yang diamati sepanjang DoY yang digunakan.

\subsubsection{Pemetaan Menggunakan GMT}

Pada penelitian ini pemetaan arah dan besar pergerakan stasiun SuGAr menggunakan software GMT 5.4.5 (Generic Mapping Tools). Masukan yang digunakan untuk pemetaan adalah hasil keluaran data posisi dari GLOBK yaitu data perubahan posisi titik koordinat toposentrik harian masing-masing stasiun SuGAr. Selain untuk pemetaan deformasi, GMT juga digunakan untuk pemetaan posisi stasiun SuGAr dan IGS.

\subsubsection{Analisis Data}

Setelah pengolahan data, dilakukan analisis data fase praseismik gempa bumi. Besar pergeseran stasiun SuGAr dapat dilihat dari nilai koordinat toposentrik dari titik asal yaitu DoY 
pertama masing-masing stasiun SuGAr ke titik terakhir yaitu DoY terakhir masing-masing stasiun SuGAr pada tahap preseismek gempa yang diamati dalam peneliian ini yaitu mulai DoY 001 sampai DoY 054. Selain itu dianalisi juga pola harian pengamatan deformasi dari DoY 001 sampai DoY 054 yang merupakan tahap praseismik gempa dari stasiun yang berada di utara, selatan dan timur dari episenter gempa

\section{HASIL DAN DISKUSI}

Untuk analisis deformasi fase praseismik gempa Februari 2008 di Segmen Mentawai digunakan data GPS dari stasiun SuGAr yang berada satu segmen dengan episenter gempa, yaitu Segmen Sipora Pagai. Dari data posisi hasil pengolahan GAMIT/GLOBK diketahui bahwa stasiun SuGAr merekam posisi setiap pukul 11.59 UTC (Universal Time Coordinate). Oleh karena itu, posisi dari stasiun SuGAr yang merekam deformasi pada gempa Mentawai 2008 merupakan akumulasi dari beberapa kejadian gempabumi, Gambar 1 menunjukkan episenter gempa yang mempengaruhi deformasi gempa Segmen Mentawai pada bulan Februari 2018 yang terdiri dari gempa foreshock mencapai kekuatan $6,5 \mathrm{M}_{\mathrm{w}}$, gempa utama $7,2 \mathrm{M}_{\mathrm{w}}$, dan 2 kejadian gempa aftershock berkekuatan $\geq 6$ $\mathbf{M}_{\mathrm{w}}$. Hasil yang akan diuraikan dalam pembahasan ini meliputi analisis data time series harian, perhitungan vektor kecepatan dan visualisasi vektor kecepatan pada tahap praseismik yang dianalisis mulai dari DoY 001 sampai DoY 054. Berdasarkan pengolahan data GPS stasiun SuGAr yaitu BSAT, PRKB, SLBU, SMGY, KTET, PPNJ, dan MKMK yang berada di daerah penelitian, diperoleh data posisi harian berupa time series.

\subsection{Deformasi dan Visualisasi Grafik Time Series}

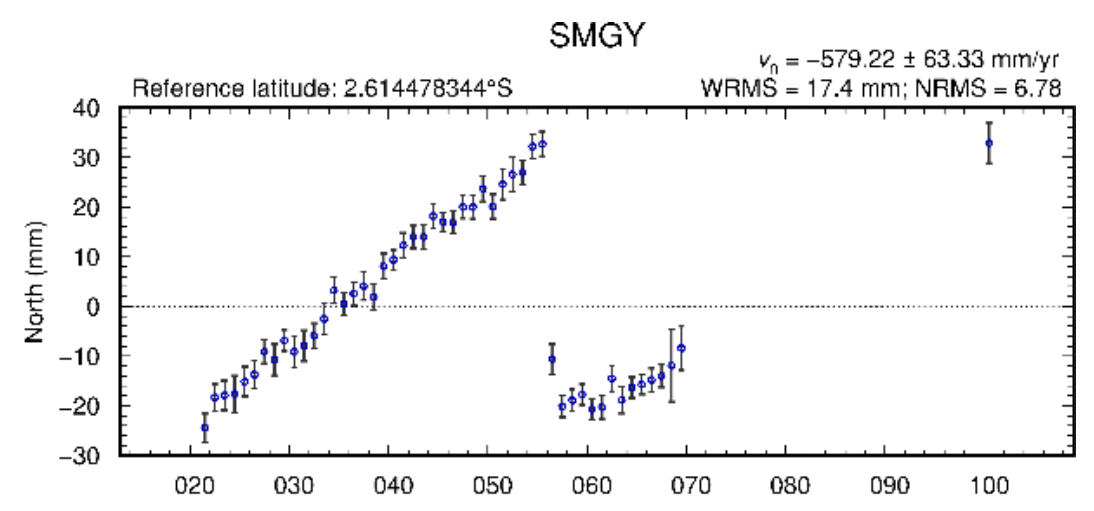

(a)

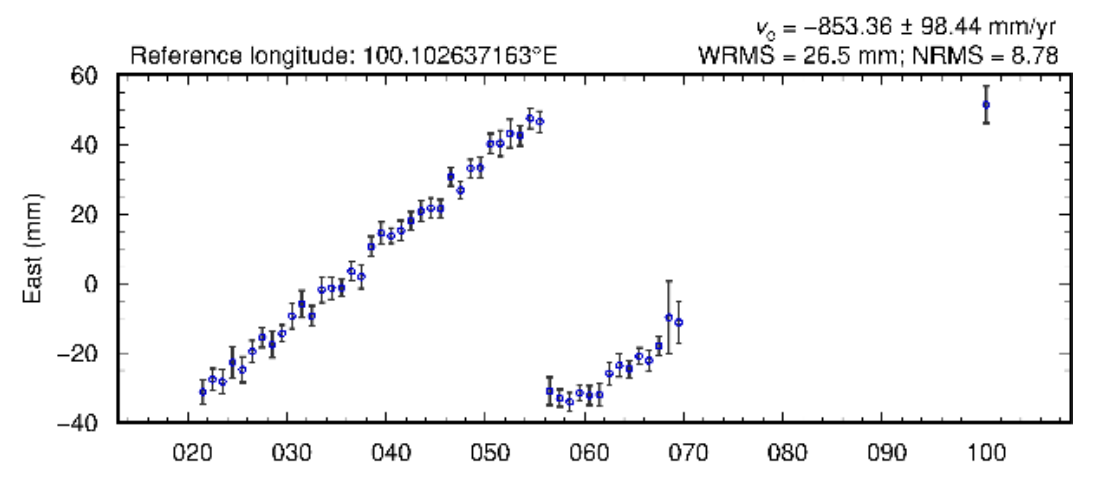

(b)

Gambar 2. Time series stasiun SMGY untuk (a) sumbu utara dan (b) sumbu timur

Time series dari stasiun SMGY diperlihatkan pada Gambar 2. Time series ditunjukkan pada sumbu utara dan timur. Arah deformasi dari stasiun SMGY adalah North East pada tahap praseismik 
(pada DoY 001 sampai 054) yang sesuai dengan arah penunjaman dari Lempeng Indo-Australia terhadap Lempeng Eurasia. Pada tahap ini, energi terakumulasi akibat tekanan Lempeng Indo-Austalia terhadap Lempeng Eurasia. Pada saat terjadi gempa, energi yang terakumulasi akibat penunjaman Lempeng Indo-Australia dilepaskan. Hal ini disebabkan gaya tekan Lempeng Indo-Australia telah melebihi batas elastisitas batuan pada daerah di sekitar episenter gempa. Energi yang dilepas menyebabkan batuan terlenting. Hal ini ditunjukkan dengan besar deformasi yang signifikan dan berlawanan arah dengan arah praseismik atau disebut coseismic jump. Selanjutnya pada tahap pascaseismik (DoY 057 hingga pada DoY 100) stasiun SMGY belum menunjukkan arah deformasi seperti tahap praseismik. Hal ini disebabkan kondisi batuan yang belum stabil karena pelepasan sisa energi. Kondisi batuan yang belum stabil ini membutuhkan waktu yang panjang guna kembali ke arah deformasi semula.
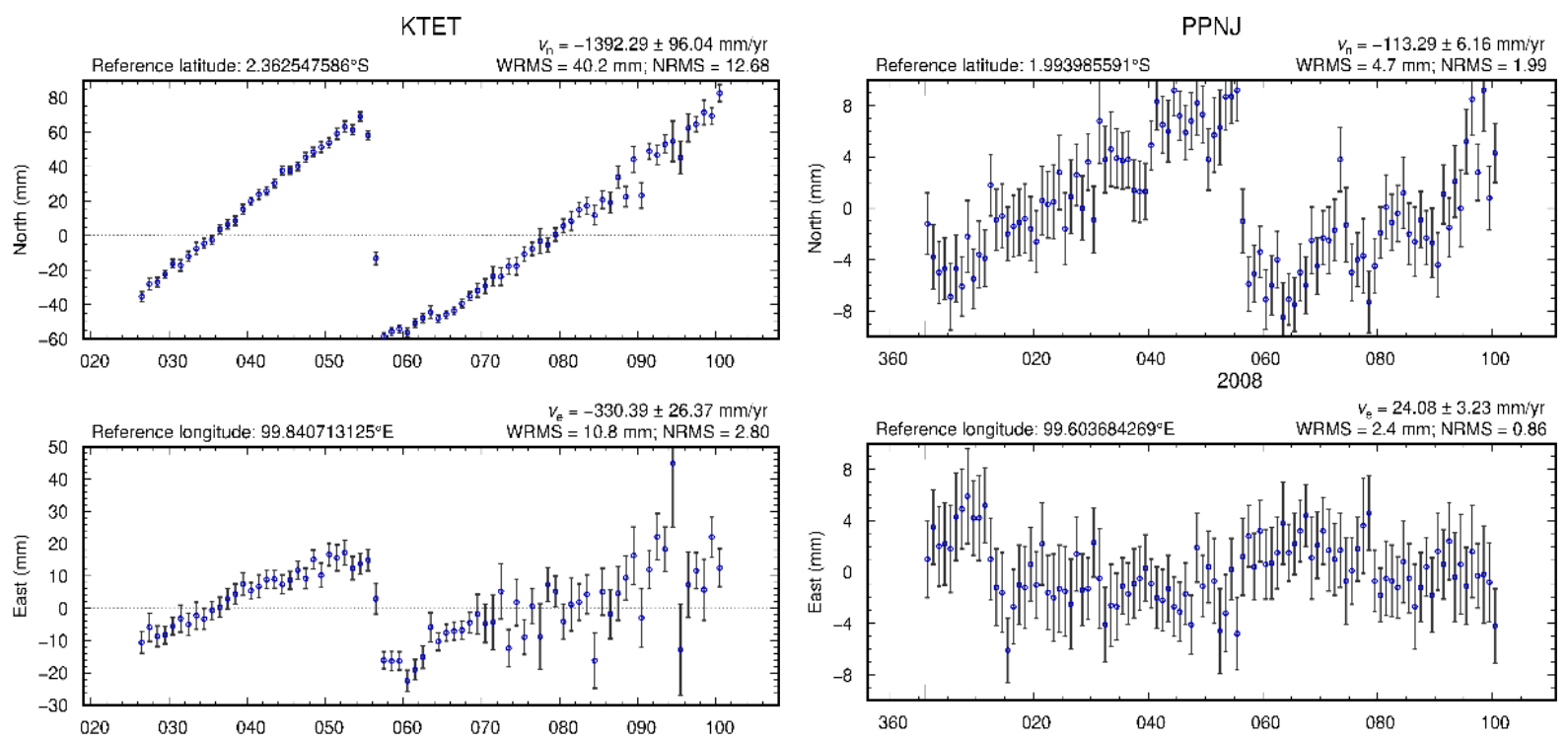

(a)

(b)
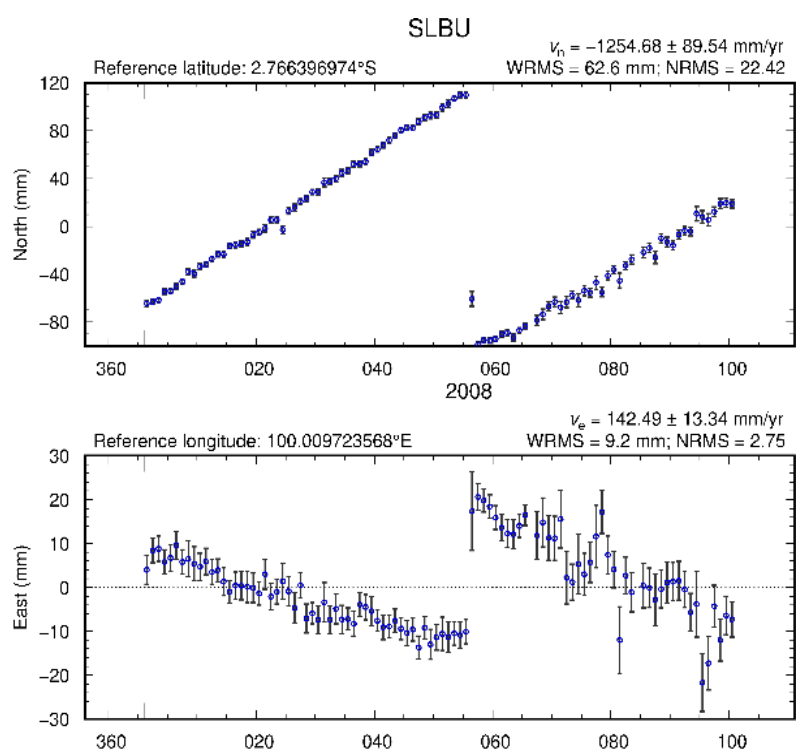

(c)

Gambar 3. Timeseries stasiun (a) KTET, (b) PPNJ, dan (c) SLBU 
Gambar 3 menunjukkan time series dari stasiun KTET, PPNJ, dan SLBU. Dapat dilihat arah deformasi dari stasiun KTET adalah North East pada tahap praseismik (DoY 001 samapai DoY 054) yang sesuai dengan arah penunjaman terus-menerus dari Lempeng Indo-Australia terhadap Lempeng Eurasia. Arah deformasi North West teramati pada stasiun PPNJ dan SLBU. Pada tahap ini, energi terakumulasi akibat tekanan Lempeng Indo-Austalia terhadap Lempeng Eurasia. Coseismic jump yang terjadi pada ketiga stasiun ini juga memiliki besar yang berbeda, hal ini karena semakin dekat stasiun terhadap episenter gempa, semakin besar deformasi yang terjadi. Selanjutnya pada tahap pascaseismik (DoY 057 sampai DoY 100), stasiun-stasiun belum menunjukkan arah deformasi seperti tahap praseismik dan membutuhkan waktu jangka panjang untuk kembali ke arah deformasi semula.
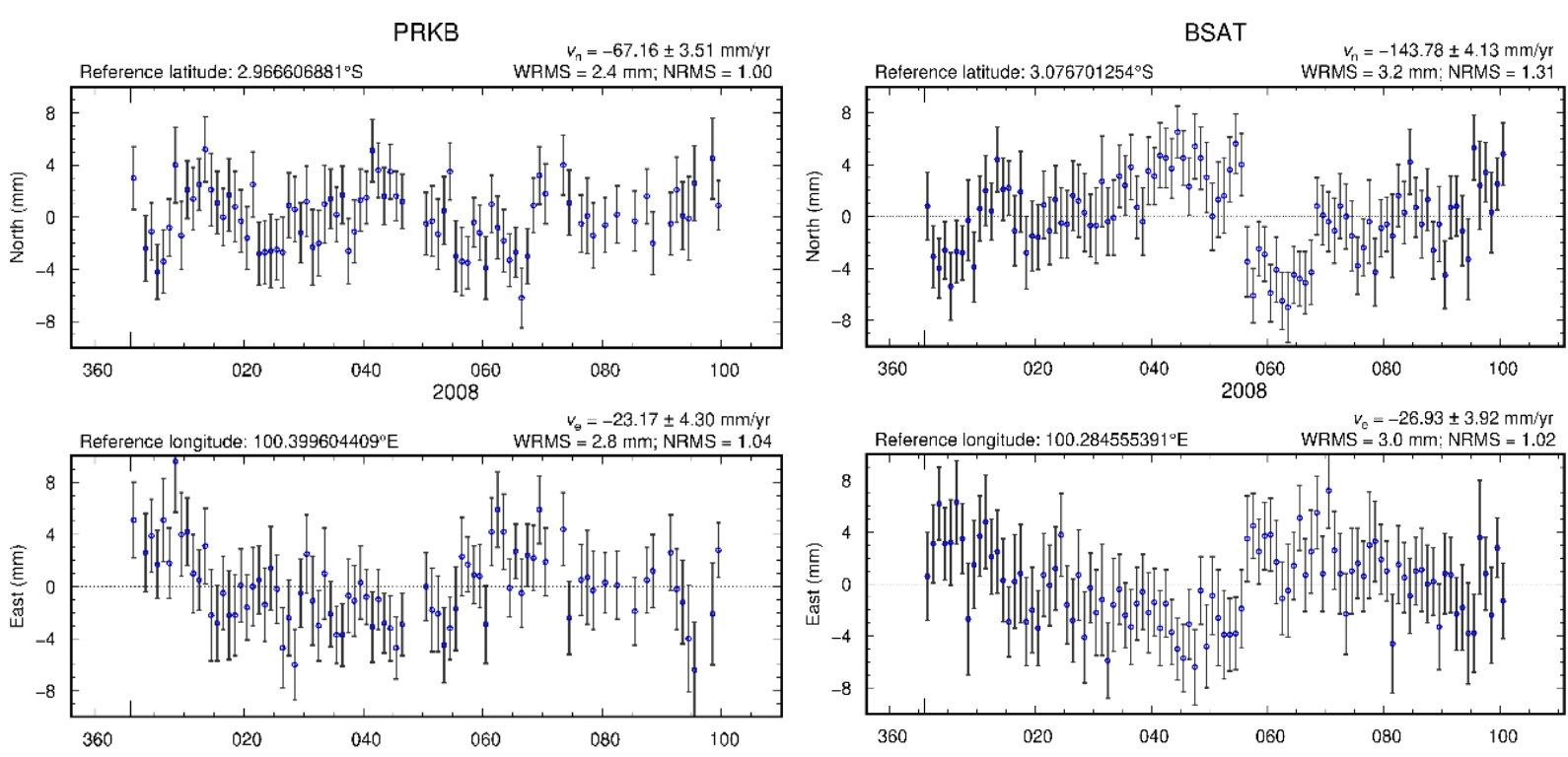

(a)

(b)
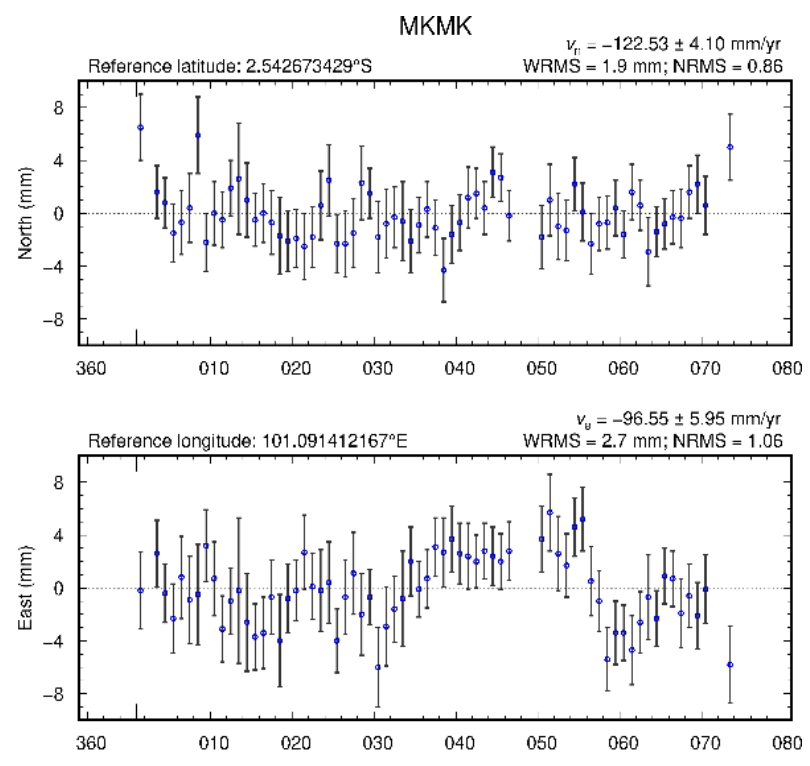

(c)

Gambar 4. Timeseries sumbu utara dan timur stasiun SuGAr (a) PRKB, (b) BSAT, dan (c) MKMK

Time series stasiun PRKB, BSAT, dan MKMK ditunjukkan pada Gambar 4. Arah deformasi ketiga stasiun ini tidak terlihat jelas. Hal ini karena posisi ketiga stasiun ini lebih jauh terhadap episenter dibandingkan dengan stasiun SMGY, SLBU, PPNJ, dan KTET. 
Time series yang diperoleh dari hasil penelitian ini sesuai dengan hasil deformasi fase pascaseismik yang diperoleh Muafiry dkk. (2014) yaitu arah vektor pergeseran stasiun GPS SuGAr SLBU, BSAT, PRKB yang terletak pada pulau Pagai Selatan pada fase pascaseismik Gempa Mentawai 25 Februati 2008 adalah south-west, sedangkan stasiun PPNJ pada fase pascaseismik adalah south-East. Arah pergerakan stasiun yang berada pada Pulau Pagai Selatan ke arah south-west ini berbanding lurus dengan vektor pergeseran stasiun GPS pascaseismik Gempa Mentawai 2007 yang sebelumnya telah diteliti oleh Yusfania, dkk. (2014), yang arah vektornya south-west. Hal ini disebabkan Gempa Mentawai 2008 merupakan rentetan aftershock atau masih pada tahap pacaseismik dari Gempa Mentawai 2007.

\subsection{Analisis Vektor Pergeseran Praseismik Gempa Februari 2008}

Dengan melihat analisis vektor pergeseran fase praseismik gempa Februari 2008 berdasarkan posisi stasiun terlihat bahwa pergeseran terbesar terjadi di stasiun yang memiliki jarak yang dekat dengan episenter gempa dibandingkan dengan stasiun yang memiliki jarak jang lebih jauh dari episenter gempa. Perubahan nilai deformasi harian pada semua stasiun yang diamati tidak memiliki pola yang jelas pada tahap praseismik yang diamati pada DoY 001 sampai DoY 054. Terjadi penurunan nilai deformasi untuk beberapa hari tapi tidak berlangsung konstan sampai menjelang terjadinya gempa untuk semua stasiun. Tidak ditemukan adanya anomali deformasi berupa akselerasi deformasi sebelum terjadi gempa 25 Februari 2008

Tabel 1 menunjukkan vektor deformasi dan besar perpindahan praseismik selama 54 hari sebelum Gempa Mentawai 2008. Besar deformasi berkisar 0,7 mm hingga 5,9 mm untuk stasiun BSAT, PRKB, PPNJ, dan MKMK. Sedangkan untuk stasiun SLBU, KTET, dan SMGY besar deformasi berkisar $35 \mathrm{~mm}$ hingga $103 \mathrm{~mm}$. Stasiun SLBU memilik deformasi terbesar yaitu 103.4364 $\mathrm{mm}$ dengan jarak terdekat pada episenter gempa seperti terlihat pada Gambar 1. Adanya vektor pergeseran yang lebih besar pada suatu stasiun yang paling dekat dengan episenter gempa dibandingkan dengan stasiun lainnya pada fase sebelum gempa Februari 2008 mengindikasikan kemungkinan gempa akan terjadi di sekitar stasiun GPS tersebut seperti yang terlihat pada hasil penelitian ini. Vektor pergeseran terbesar terjadi pada 3 stasiun yang terdekat dengan episenter gempa yaitu SLBU, KTET dan SMGY. Hal ini sesuai dengan penelitian yang dilakukan oleh Yusfania, dkk. (2014) dan Sajagat dkk. (2016) yang memperoleh hasil bahwa pada fase sebelum gempa, stasiun SuGAr yang memiliki pergeseran paling besar adalah stasiun yang berada paling dekat dengan lokasi episenter gempa. Pada tahap praseismik terlihat dengan jelas tren peningkatan deformasi pada stasiunstasiun yang berdekatan dengan episenter gempa dibandingkan stasiun yang lebih jauh dari episenter gempa walaupun kisarannya hanya berubah dalam millimeter saja.

Gambar 5 menunjukkan arah deformasi praseismik Gempa Mentawai 2008 berdasarkan ratarata vektor deformasi DoY ke-054 erhadap DoY 001. Dapat dilihat bahwa arah deformasi praseismik searah dengan laju deformasi akibat subduksi Lempeng India-Australia terhadap Lempeng Eurasia, yaitu North - East.

Tabel 1 Vektor Deformasi Praseismik Gempa Mentawai 2008

\begin{tabular}{lrrr}
\hline Stasiun & dE $(\mathbf{m m})$ & $\mathbf{d N}(\mathbf{m m})$ & \multicolumn{1}{c}{$\mathbf{D}(\mathbf{m m})$} \\
\hline BSAT & $-4,007520$ & 4,374876 & 5,932939 \\
PRKB & $-3,651290$ & 2,081684 & 4,203018 \\
SLBU & $-9,851820$ & 102,993300 & 103,463400 \\
SMGY & 29,154710 & 19,670240 & 35,169810 \\
KTET & 20,071000 & 94,844640 & 96,945090 \\
PPNJ & 0,027168 & 0,775420 & 0,775896 \\
MKMK & 0,133580 & $-3,606770$ & 3,609241 \\
\hline
\end{tabular}




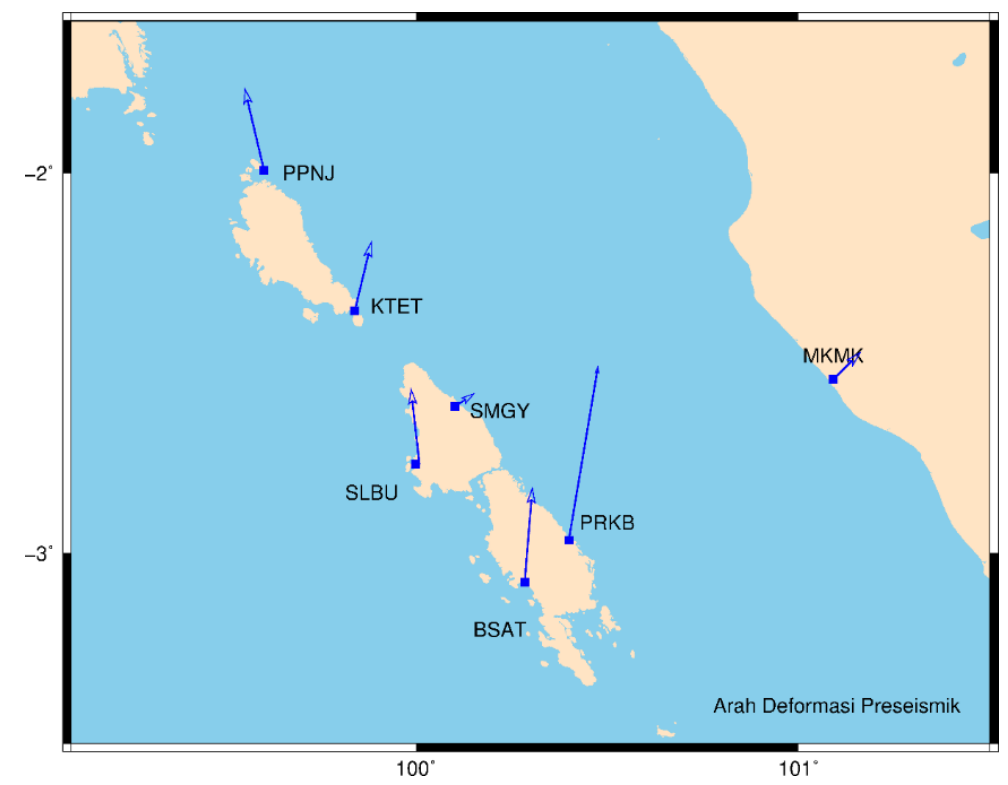

Gambar 5 Arah Deformasi Praseismik Gempa Mentawai 2008

\section{KESIMPULAN}

Hasil penelitian ini memperlihatkan arah deformasi praseismik sebelum terjadi gempa Mentawai 25 Februari 2008 searah dengan laju deformasi akibat subduksi Lempeng India-Australia terhadap Lempeng Eurasia, yaitu North-East. Namun, perubahan deformasi harian pada semua stasiun tidak memiliki pola yang jelas. Terjadi penurunan nilai deformasi untuk beberapa hari tetapi tidak berlangsung lama. Hal ini teramati pada semua stasiun baik yang berada di sebelah utara, timur atau selatan episenter gempa. Selain itu tidak dietemukan adanya akselerasi deformasi sebelum terjadi gempa 25 Februari 2008. Hasil penelitian ini menemukan adanya pemusatan energi selama fase praseismik pada daerah di sekitar episenter gempa seperti di Pulau Sipora dan Pagai. Nilai deformasi pada pulau ini seperti yang teramati pada stasiun KTET, SLBU, dan SMGY lebih besar dari stasiun BSAT, PRKB, PPNJ dan MKMK. Hal ini konsisten dengan lokasi episenter Gempa Mentawai 2008 yang berada di daerah ini. Hasil penelitian ini menegaskan pentingnya pengamatan deformasi praseismik dalam rangka pemantauan potensi dan mitigasi bencana alam gempa bumi.

\section{UCAPAN TERIMA KASIH}

Penulis berterima kasih kepada pihak FMIPA Universitas Andalas yang telah mendanai penelitian ini melalui Dana PNBP FMIPA Universitas Andalas, dengan kontrak penelitian Nomor: 09/UN.16.03.D/PP/FMIPA/2019, tahun anggaran 2019 dan pihak Pusat Penelitian Geoteknologi LIPI, yang memberi kemudahan akses untuk penggunaan dan pengolahan data GPS SuGAr yang digunakan dalam penelitian ini.

\section{DAFTAR PUSTAKA, (STYLE TEMPLATE 610.JUDUL BAB TANPA NOMOR)}

Aji, Y.W. (2016). Pengolahan Data GPS Menggunakan Software GAMIT 10.6 dan TOPCON Tools V.8 pada Pengukuran Deformasi Bendungan Jatibarang, Jurnal Geodesi Undip, Universitas Diponegoro.

Ardiansyah, S. 2014, Energi Potensial Gempa Bumi di Kawasan Segmen Mentawai Sumatera Barat $\left(0,5^{\circ}\right.$ LS $4,0^{\circ}$ LS dan $\left.100^{\circ} \mathrm{BT}-104^{\circ} \mathrm{BT}\right)$, PSJ, Akademi Meteorologi dan Geofisika, Jakarta.Vol. 2, No. 1, 2014 : $1-9$.

Bock, L.Y., \& Prawirodirdjo, J.F. (2003). Crustal Motion in Indonesia from Global Positioning System Measurements, Journal of Geophysical Research, 108(8), 2367. 
Efendi., Prijatna, K., \& Meilano, I. (2018). Analisis Pergeseran Koseismik Gempa Sianok Tahun 2007 Berdasarkan Data Pengamatan GPS Tahun 1993-2007 dan Efek terhadap SRGI 2013, Jurnal Online Institut Teknologi Nasional, 2018 (1) : 1-18.

Feng, Lujia. (2015). A Unified GPS-based Earthquake Catalog for The Sumatran Plate Boundary Between 2002 and 2013, Journal of Geophysical Research : Solid Earth, 3566-3598, doi 10.1002/2014JB011663.

Herring, T.A., King, R.W., \& McClusky, S. C. (2008). Introduction to GAMIT/ GLOBK: Departement of Earth Atmospheric and Planetary Sciences MIT.

Mori, J. (2004). Earthquake Prediction. Lectures notes on KAGI 21 Summer School: Institut Teknologi Bandung.

Muafiry, I.N. (2014). Analisis Vektor Pergeseran Postseismic Stasiun GPS SuGAr Akibat Gempa Mentawai 2008 (Skripsi). Teknik Geomatika Fakultas Teknik Sipil dan Perencanaan, Institut Sepuluh Nopember.

Natawidjaja, D. H. (2007). The Sumatran Fault Zone from Source to Hazard, Journal of Earthquake and Tsunami, World Scientific Publishing, 1(1) : 21-47.

Nurdianasari. (2017), Analisis Deformasi Postseismik Gempa Nias 2005 Menggunakan Data GPS (Skripsi). Departemen Teknik Geodesi Fakultas Teknik, Universitas Diponegoro.

Rahmad, A. A. (2016). Analisa Pengolahan Data Stasiun GPS CORS Gunung Merapi Menggunakan Perangkat Lunak Ilmiah GAMIT/GLOBK 10.6, Jurnal Teknik ITS, Vol. 5, No. 4, hal 43 - 438, Jurusan Teknik Geomatika, ITS, Surabaya.

Sajagat, M.J., Awaluddin., \& Yuwono, B.D. (2016). Hitungan Kecepatan Pergerakan Stasiun SUGAR Akibat Proses Interseismik Gempa Mentawai 2007, Jurnal Geodesi Undip, Vol. 5, No. 4, hal 196-206, Program Studi Teknik Goedesi, UNDIP, Semarang.

Sarsito, D.A., Andreas, Abidin, H.Z., Meilano, I., Darmawan, \& Gamal. (2005). Implikasi Co-Seismic dan Post-Seismic Horisontal Displacement Gempa Aceh 2004 terhadap Status Geometrik Data Spasial Wilayah Aceh dan Sekitarnya: Kelompok Keahlian Geodesi, Departemen Teknik Geodesi, Institut Teknologi Bandung.

Sieh, K., \& Natawidjaja, D.H. (2000), Neotectonic of the Sumatran Fault; Indonesia, Journal of Geophysical, vol. 105, No B12, hal. 28295 - 28326

Yusfania, M., Ihsan, F.U., \& Cahyadi, M. N. (2014). Analisis Pergeseran Akibat Gempa Bumi Sumatra 11 April 2012 Menggunakan Metode GPS, Jurnal GEOID, Vol. 11,No. 01, hal 57-61, ITS, Surabaya. 